\title{
Design of Smart Bin for Waste Management
}

\author{
Ashish R.Yadav ${ }^{1}$, Shreekrushna N.Chahakar ${ }^{2}$, Satya S.Singh ${ }^{3}$, Ravikumar C.Bisen ${ }^{4}$, \\ Bhuneshwar Y.Chauragade ${ }^{5}$, Prof. Swapnil Chaudhary ${ }^{6}$, Prof. Bharat Chede ${ }^{7}$ \\ ${ }^{1,2,3,4,5}$ U.G.Student, Wainganga Collage of Engineering \&Management, Maharashtra, India \\ ${ }^{6,7}$ Assistant Professor, Wainganga Collage of Engineering \&Management, Maharashtra, India
}

\begin{abstract}
Food waste management is a challenge for the cities' authorities in developing countries mainly due to the increasing generation of waste, the burden posed on the municipal budget as a result of the high costs associated to its management, the lack of understanding over a diversity of factors that affect the different stages of waste management and linkages necessary to enable the entire handling system functioning.
\end{abstract}

\section{Keywords- Green Dustbin, Waste Management}

\section{I- INTRODUCTION}

$I$ ndia is the second largest producer of fruits and vegetables in the world with 221.431 million metric tons. Rapid industrialization and population growth in India has led to the migration of people from villages to cities thereby generating thousands of tons of municipal solid waste everyday throughout the country. Urban India is reported to generate 68.8 million tons of MSW (Municipal solid waste) per year with a per capita waste generation rate of $500 \mathrm{~g} /$ person/day.

\section{II -METHOLOGY}

The objective of this thesis was to increase our knowledge of issues relevant to process problems in large-scale composting. Composting is a potential recycling process in which resources are conserved in a more available form so that they can be efficiently used. Agriculture is receiving huge attention worldwide, as government and non-government authorities recognize that there is need to increase productivity in a more accelerated way in order to ensure food security and improved nutrition to a growing population. As due to increase in wastage of vegetables we go through research paper, need of the machine to utilize this wastage in proper way

\section{III - PROCESSING OF COMPOSTING}

Process stages: digestion involve hydrolysis, acidogenesis,acetogenesisand methanogens.[17] The overall process can be described by the chemical reaction, where organic material such as glucose is biochemically digested into carbon dioxide (CO2) and methane $(\mathrm{CH} 4)$ by the anaerobic microorganisms.

\section{Hydrolysis}

In most cases, biomass is made up of large organic polymers. For the bacteria in anaerobic digesters to access the energy potential of the material, these chains must first be broken down into their smaller constituent parts. These constituent parts, or monomers, such as 


\section{International Journal of Innovations in Engineering and Science, www.ijies.net}

sugars, are readily available to other bacteria. The process of breaking these chains and dissolving the smaller molecules into solution is called hydrolysis. Therefore, hydrolysis of these high-molecular-weight polymeric components is the necessary first step in anaerobic digestion. Through hydrolysis the complex organic molecules are broken down into simple sugars amino acids, and fatty acids.

Acetate and hydrogen produced in the first stages can be used directly by methanogens. Other molecules, such as volatile fatty acids (VFAs) with a chain length greater than that of acetate must first be catabolized into compounds that can be directly used by methanogens.

\section{Abiogenesis}

The biological process of Abiogenesis results in further breakdown of the remaining components by acid genic (fermentative) bacteria. Here, VFAs are created, along with ammonia, carbon dioxide, and hydrogen sulfide as well as other byproducts. The process of abiogenesis is similar to the way milk sours.

\section{Acetogenesis}

The third stage of anaerobic digestion is Acetogenesis Here, simple molecules created through the acid genesis

$$
\mathrm{C}_{6} \mathrm{H}_{12} \mathrm{O}_{6} \rightarrow 3 \mathrm{CO}_{2}+3 \mathrm{CH}_{4}
$$

phase are further digested by acetones to produce largely acetic acid, as well as carbon dioxide and hydrogen.

\section{Methanogens}

The terminal stage of anaerobic digestion is the biological process of methanogens. Here, methanogens use the intermediate products of the preceding stages and convert them into methane, carbon dioxide, and water. These components make up the majority of the biogas emitted from the system. Methanogenesis is sensitive to both high and low pHs and occurs between $\mathrm{pH} 6.5$ and $\mathrm{pH}$ 8. The remaining, indigestible material the microbes cannot use and any dead bacterial remains constitute the digestate.

\section{IV- DESIGN}

Design of cylinder

$\mathrm{Pi}=\mathrm{W} \times \mathrm{H}$

$=9810 \times 0.19$
$=2.19 \mathrm{~N} / \mathrm{sq}-\mathrm{mm}$

Design of shaft

Power of Motor $=0.5 \mathrm{Hp}=373 \mathrm{~W}$

$\mathrm{P}=2 \times 3.14 \times \mathrm{N} \times \mathrm{T} / 60$

$373=2 \times 3.14 \times 30 \times \mathrm{T} / 60$

So, $\mathrm{T}=118.73 \mathrm{Nm}$

Design of base

$$
\begin{aligned}
& \mathrm{X} 1=5 / 2=2.5 \mathrm{~cm} \\
& \mathrm{X} 2=5+68 / 2=39 \mathrm{~cm} \\
& \mathrm{X} 3=5+68+5 / 2=75.5 \mathrm{~cm}
\end{aligned}
$$

As the given base is symmetrical about $\mathrm{X}$ axis, so $\mathrm{Y} 1=\mathrm{Y} 2=\mathrm{Y} 3=25.5 \mathrm{~cm}$

Xcentre $=(51 \times 5 \times 2.5+68 \times 5 \times 39+51 \times 5 \times 75.5) /(51$

$\times 5+68 \times 5+51 \times 5)$

$X$ center $=39 \mathrm{~cm}$

\section{V- BLOCK DIAGRAM}

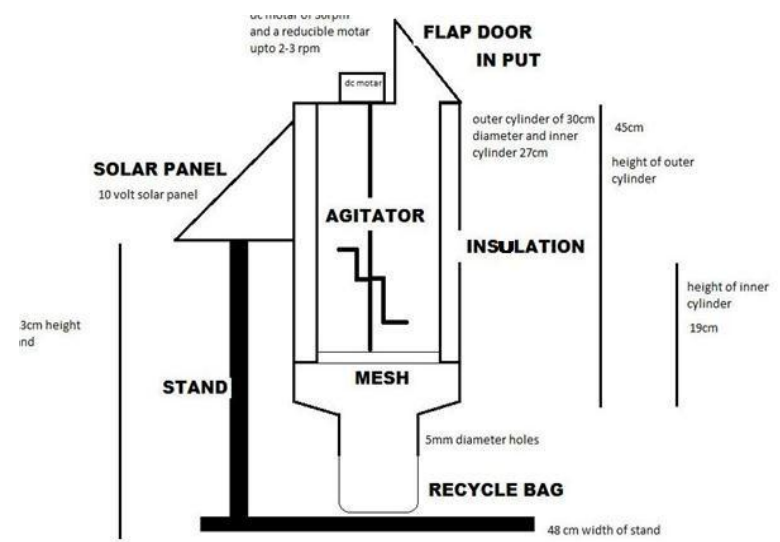

\section{VI - CONCLUSION}

Drum composting of vegetable waste was successful with the combination of cow dung, saw dust and dried leaves. The 20 days of operation was found highly efficient for producing stabilized compost within shorter time. Appropriate addition of efficient material plyed a major role in the degradation process. The successful operation of vegetable waste composting is followed out by adding appropriate quantity of bulking agent such as saw dust and dry leaves to maintain the thermophilie phase and increase the efficiency of process. Since, lower addition of bulking agents during the process might lead to the production of lechate thereby deteriorating the quality of compost. However, higher addition of bulking agent might add more 
Vol. 6, No. 8, 2021, PP. 41-43

\section{International Journal of Innovations in Engineering and Science, www.ijies.net}

lignocellulose concentration to end the product, which might take longer time for further degradation.

Maintenance of longer thermophile phase during the process proved to be crucial in the elimination of pathogens and degradation of lignocellulose fractions. Despite of various microbial communities during vegetable waste composting, each community was observed to act accordingly to temperature and nature of substrate available. Microbial population growth was influenced by the temperature and also effective organic matter degradation. However, combination of waste material played a major role in favoring microbial succession. The final end product was completely stabilized with lower oxygen uptake rate and CO2evaluation rate at the end of composting period.

\section{ACKNOWLEDGMENT}

Acknowledgment to person or the organization supported to the author for the research work. This is not mandatory for all.

\section{REFERENCES}

[1] Annepu, R.K. (2012). Sustainable SoildWsate Management in India, Earth Engineering Center. Columbia University, New York.

[2] Manual on Muncipal Solid Waste Management (2000). Ministry of Urban Development, GOI.

[3] Diaz, M.J., Madejon, E., Lopez., F., Lopez, R., and Cabrera, F. (2007). "Optimization of he rate vinase lgrape for co-composting process ."proc. Biochem. ,37(10), 1143-1150

[4] UNEP.(2014).

http://www.unep.or.jp/ietc/estdir/pub/msw/sp/sp4/sp4_1.a $s p$.

[5] JnNURM (Jawaharlal Nehru National Urban Renewal Mission).(2012). Toolkit for solid waste Management ,Ministry of Urban Development, GOI.

[6] Chiang , K.Y.,Haung , H.J., and Chang, C. N. (2007). "Enhancement of heavy metalstabilization by different amendments during sewage sludge composting ." J. Environ. Eng. Manage., 17(4),249-256.

[7] Qiao and Ho, 197; Wong et al., 1997; Fang and Wong, 1999, Singh and Kalamdhad, 2013; Singh and Kalamdhad,2014

[8] journal homepage: www.elsevier.com/locate/wasman

[9] European Commission (2010):Communication from the Commission to the Council and European Parliament on future steps in bio-waste management in the European Union
[10] Personal communication with Ashley Zanolli, EPA Region http://www.epa.gov/waste/conservelfoodwastelfdreduce.htm

[11]Atlas, R. M. \&Bartha, R. 1998. Microbial ecology. Fundamentals and applications. 4. Addison Wesley Longman. Menlo Park, California. 694 pp.

[12] US EPA. Basic Information about Food Waste. Available online: http://www.epa.gov/osw/conserve/ 